\title{
In-vitro cytotoxic activities of poly(2-ethyl-2-oxazoline)-based amphiphilic block copolymers prepared by CuAAC click chemistry
}

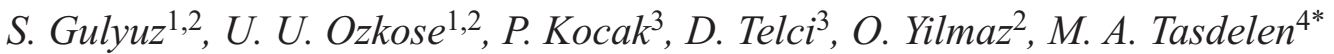 \\ ${ }^{1}$ Department of Chemistry, Faculty of Science and Letters, Istanbul Technical University, Maslak, TR-34469 Istanbul, \\ Turkey \\ ${ }^{2}$ Materials Institute, Marmara Research Center, TUBITAK, Gebze, TR- 41470 Kocaeli, Turkey \\ ${ }^{3}$ Department of Genetics and Bioengineering, Faculty of Engineering and Architecture, Yeditepe University, 26 Agustos \\ Campus, Istanbul, Turkey \\ ${ }^{4}$ Department of Polymer Engineering, Faculty of Engineering, Yalova University, TR-77100 Yalova, Turkey
}

Received 2 June 2017; accepted in revised form 30 September 2017

\begin{abstract}
Synthesis and characterization of well-defined amphiphilic block copolymers containing poly(2-ethyl-2-oxazoline) as hydrophilic block and poly(E-caprolactone) or poly(L-lactide) as hydrophobic block is achieved by copper-catalyzed azide-alkyne cycloaddition (CuAAC) click chemistry. The clickable precursors, $\alpha$-alkyne-functionalized poly( $\varepsilon$-caprolactone) and poly(L-lactide) and $\omega$-azido-functionalized poly(2-ethyl-2-oxazoline) are simply prepared and joined using copper sulfate/ascorbic acid catalyst system at room temperature. The structures of precursors and amphiphilic block copolymers are characterized by spectroscopic, chromatographic and thermal analyses. The cytotoxic activities of resulting amphiphilic block copolymers and their precursors are investigated in the prostate epithelial and cancer cells under in-vitro conditions. The treatment of the healthy prostate epithelial cell line PNT1A reveals that no significant cytotoxicity, whereas some significant toxic effects on the prostate cancer cell lines are observed.
\end{abstract}

Keywords: polymer synthesis, molecular engineering, amphiphilic block copolymers, copper-catalyzed azide-alkyne cycloaddition click chemistry, in-vitro cytotoxic activity, polyoxazolines

\section{Introduction}

Amphiphilic block copolymers that consist of hydrophilic and hydrophobic segments, represent a new class of functional materials serving a number of applications mainly drug delivery, pharmaceutics, separation, surfactant and coating [1]. By changing various parameters such as hydrophilic/hydrophobic block ratio, polymer concentration, temperature and polymer-solvent interaction, they can self-assemble into a wide variety morphologies including bilayer-type, cylindrical or spherical micelles, vesicles and nanotubes [2]. Since the amphiphilic block copolymers deliberately require precise molecular characteristics, only controlled polymerization methods are able to prepare these type of copolymers [3]. The combination of these methods with highly efficient 'click' chemistry reactions are great opportunities for the synthesis of complex macromolecular architectures [4]. This combination is very useful to join the chemically incompatible blocks in a single molecule, such as a block and a graft copolymer, a star-shaped polymer, a hybrid material, and a bioconjugate [5-10].

After the discovery of the CuAAC click reaction [11], it has become a universally used method in chemical sciences, especially in drug discovery, medicinal, 
polymer and material sciences [12]. Due to its high efficiency, less by-products and high tolerance of functional groups, many complex macromolecular architectures can be easily prepared with tailored topologies, compositions and microstructures [13]. One of the first examples of this CuAAC click reactions was demonstrated by Van Hest and coworkers for the modular synthesis of amphiphilic block copolymers $[14,15]$. And then, many groups have extensively used this 'click' reaction to synthesize a wide variety of block copolymers (such as $\mathrm{AB}, \mathrm{ABC}$, $\mathrm{ABA},(\mathrm{AB})_{\mathrm{n}}$, etc.) [16-22]. To take advantage of this efficient strategy, recently, the poly(2-alkyl-2-oxazoline)-based amphiphilic block copolymers can be simply prepared by combination of coordination-insertion ROP (ring opening polymerization) and living CROP (cationic ring opening polymerization) with CuAAC click reactions [23, 24]. Both hydrophilic and hydrophobic blocks are biocompatible, therefore, these block copolymers have promising potentials for drug delivery applications.

Recently, owing to the their unique nontoxicity, biodegradable and biocompatible features, aliphatic polyesters, such as poly( $\varepsilon$-caprolactone) (PCL), polylactide (PLA) and their block copolymers are intensively studied in the biomedical applications, such as in controlled drug release systems and absorbable sutures [25]. However, these aliphatic polyesters have several disadvantages including their low solubility and lack of reactive sites for further functionalization, which limit their usage in biomedical applications [26]. The introduction of pendent functional groups or hydrophilic segments along these aliphatic polyester chains enables to adjust their physicochemical properties, such as crystallinity, hydrophilicity, bioadhesion, biological activity and biodegradation rate [27]. Up to now, various modification strategies for example, functional initiators or monomers, copolymerization and post-modification reactions are applied for the functionalization aliphatic polyesters [28, 29]. Recently, poly(2-oxazoline)s have drawn attention with the finding of the potential biological and chemical favorability due to their some advantageous structural properties such as $\mathrm{pH}$ and temperature sensitive, ionic strength, chemical and biological stimuli [30-34]. These polymers can be obtained via living cationic ring opening polymerization (CROP) of 2-alkyl-oxazolines and functionalized by using either functional initiator or nucleophilic terminating agents [35-39]. Among them, poly(2-oxazoline)s with short side chains (ethyl, $n$ and iso-propyl), except for 2-methyl-2-oxazoline, permit easy access to amphiphilic and well-defined block copolymers owing to the lower critical solution temperature (LCST) behavior in aqueous solutions and thermoresponsive properties [35-39].

To date, poly(2-oxazoline)s are obtained utilizing various initiators including halides such as benzyl bromide, alkyl esters such as methyl tosylate, methyl triflate and Lewis acids such as boron trifluoride $\left(\mathrm{BF}_{3}-\mathrm{OEt}_{2}\right)$ [40-42]. Moreover, poly(2-oxazoline)s are functionalized with many terminating agents such as water, hydroxyl ion in methanolic sodium hydroxide solution, ammonia, piperidine, sodium azide etc [43-47].

In this work, we reported the synthesis and characterization of amphiphilic block copolymers containing poly(2-ethyl-2-oxazoline) as hydrophilic segment and poly( $\varepsilon$-caprolactone) or poly(L-lactide) as hydrophobic segments by combination of coordinationinsertion ring opening polymerization (ROP) and living CROP with CuAAC click chemistry. With this aim, the clickable azide-functionalized poly(2-ethyl2-oxazoline) (PEtOx-N 3 ) was prepared by living CROP of 2-ethyl-2-oxazoline, which terminated by sodium azide. Whereas, clickable alkyne-poly( $\varepsilon-$ caprolactone) (PCL-alkyne) and alkyne-poly(L-lactide) (PLA-alkyne) were synthesized via coordination-insertion ROP of $\varepsilon$-caprolactone and L-lactide using propargyl alcohol as an initiator via tin (II) 2ethylhexanoate as a catalyst. In the final step, the CuAAC of these azide and alkyne functionalized polymers was simply carried out at room temperature by using copper sulfate and ascorbic acid catalyst system [48, 49]. All precursor polymers and resulting amphiphilic block copolymers were characterized by spectroscopic, chromatographic and thermal analyses. The cytotoxic activities of these three polymers were evaluated on the prostate epithelial cell line PNT1A, and two prostate cancer lines 22RV1 (androgen independent) and LnCAP (androgen dependent) by using WST1 (cell proliferation reagent) cell viability assay for 24, 48 and 72 hours [50].

\section{Experimental}

\subsection{Materials}

2-Ethyl-2-oxazoline (EtOx, $\geq 99 \%$, 137456, Aldrich, Germany) and $\varepsilon$-caprolactone (CL, 99\%, 173442500, Acros, Japan) were dried over calcium hydride (95\%, 208027, Aldrich, Germany) overnight before 
distillation and then were purified by vacuum distillation. These monomers were stored under nitrogen atmosphere. L-Lactide (LA, 98\%, 367044, Aldrich, Netherlands) was purified by recrystallization from tetrahydrofuran (THF, $\geq 99.7 \%, 28559.320$, VWR, EC). Methyl para-toluenesulfonate (MeTos, $\geq 98 \%$, 158992, Aldrich, China) and propargyl alcohol (PA, 99\%, 131452500, Acros, Germany) were purified via vacuum distillation. Tin (II) 2-ethylhexanoate $\left(\mathrm{Sn}(\mathrm{Oct})_{2}, 92.5-100 \%\right.$, S3252, Aldrich, Japan) was used directly. Acetonitrile (ACN, $\geq 99.8 \%, 8149$, J. T. Baker, US) and toluene ( $\geq 99.7 \%, 32249$, Aldrich, France) were distilled from calcium hydride under reduced pressure. All other reagents for synthesis were purchased commercially and used without further purification.

\subsection{Synthesis of azide end-functionalized poly(2-ethyl-2-oxazoline) (PEtOx- $\mathrm{N}_{3}$ )}

To obtain PEtOx- $\mathrm{N}_{3}$, the published method was used [51, 52]; firstly, a flask equipped with a stirring bar was preheated via a heat gun. After being closed by a rubber, it was again heated under vacuum. After cooling under vacuum, PEtOx was prepared by living CROP of the monomer 2-ethyl-2-oxazoline (EtOx, $5 \mathrm{~mL}, 49.531 \mathrm{mmol}$ ) and with the methyl $p$-toluenesulfonate initiator (MeTos, 112,28 $\mu \mathrm{L}, 0.744 \mathrm{mmol}$ ) dissolved in acetonitrile (ACN, $15 \mathrm{~mL}$ ) under an inert atmosphere at room temperature. After polymerization for 15 hours at $130^{\circ} \mathrm{C}$, the reaction mixture was again cooled at room temperature and sodium azide $\left(\mathrm{NaN}_{3}, 193.47 \mathrm{mg}, 2.976 \mathrm{mmol}\right)$ was added for termination of the polymerization. After termination for 24 hours at $65^{\circ} \mathrm{C}$ in the dark, the solvent was removed under reduced pressure. Then, the product was dissolved in dichloromethane and precipitated in cold diethyl ether and dried under vacuum for overnight. (Yield $=4.35 \mathrm{~g}, 88.6 \% ; M_{\mathrm{n} \text {,theo }}=5850 \mathrm{Da}$; $M_{\mathrm{n}, \mathrm{NMR}}=5400 \mathrm{Da} ; M_{\mathrm{n}, \mathrm{GPC}}=9200 \mathrm{Da} ;$ polydispersity index $(\mathrm{PDI})=1.07$.

${ }^{1} \mathrm{H}-\mathrm{NMR} \quad\left(600 \mathrm{MHz}, \mathrm{CDCl}_{3}\right): \delta \quad 3.5-3.3 \quad(4 \mathrm{H}$, $\left.-\mathrm{N}-\mathrm{C}_{2}-\mathrm{C}_{2}-\right), 3.0-2.9\left(3 \mathrm{H}, \mathrm{CH}_{3}-\mathrm{N}-\mathrm{CH}_{2}-\mathrm{CH}_{2}-\mathrm{N}-\right)$, 2.4-2.2 (2H, $\left.-\mathrm{N}-\mathrm{CO}-\mathrm{CH}_{2}-\mathrm{CH}_{3}\right), 1.1-0.9(3 \mathrm{H}$, $\left.-\mathrm{N}-\mathrm{CO}-\mathrm{CH}_{2}-\mathrm{C}_{3}\right)$.

FT-IR (ATR): $v\left[\mathrm{~cm}^{-1}\right] 2100$ (azide) and 1630 (carbonyl).

\subsection{Synthesis of alkyne end-functionalized poly( $\varepsilon$-caprolactone) (PCL-alkyne)}

To obtain PCL-Alkyne, the published method was used; a ROP of epsilon-caprolactone using $\mathrm{Sn}(\mathrm{Oct})_{2}$ as a catalyst and propargyl alcohol as an initiator was conducted [53]. Typically, CL (5 mL, $45.12 \mathrm{mmol})$ and propargyl alcohol (PA, 148,39 $\mu \mathrm{L}, 2.512 \mathrm{mmol}$ ) were added in a flask with a magnetic stirring bar, and a solution of $\mathrm{Sn}(\mathrm{Oct})_{2}(12.63 \mu \mathrm{L}, 0.039 \mathrm{mmol})$ in $5 \mathrm{~mL}$ of toluene was introduced using a syringe. The mixture was deaerated with nitrogen and then immersed in a thermostated oil bath at $120^{\circ} \mathrm{C}$ for $5 \mathrm{~h}$. After removing the solvent under reduced pressure, the resulting solid was dissolved in dichloromethane, and then precipitated into an excessive amount of cold methanol. The product was subsequently dried under vacuum oven for overnight at room temperature. $\left(\right.$ Yield $=4.2 \mathrm{~g}, 81.6 \% ; M_{\mathrm{n} \text {,theo }}=1700 \mathrm{Da}$; $M_{\mathrm{n}, \mathrm{NMR}}=2500 \mathrm{Da} ; M_{\mathrm{n}, \mathrm{GPC}}=5100 \mathrm{Da}$; polydispersity index $(\mathrm{PDI})=1.35$.

${ }^{1} \mathrm{H}-\mathrm{NMR}\left(600 \mathrm{MHz}, \mathrm{CDCl}_{3}\right): \delta 4.66(\mathrm{~s}, \quad 2 \mathrm{H}$, $\left.\mathrm{C} \underline{H}_{2}-\mathrm{C} \equiv \mathrm{CH}\right), 4.00$ (m, $\underline{\mathrm{C}}_{2} \mathrm{O}$ on $\left.\mathrm{PCL}\right), 3.65$ (t, $2 \mathrm{H}$, $\left.\mathrm{C} \underline{H}_{2} \mathrm{OH}\right), 2.50$ (s, $\left.1 \mathrm{H}, \mathrm{CH}_{2}-\mathrm{C} \equiv \mathrm{C} \underline{H}\right), 2.35-2.27$ (m, $\mathrm{C} \underline{H}_{2} \mathrm{C}=\mathrm{O}$ on $\left.\mathrm{PCL}\right), 1.67-1.57\left(\mathrm{~m}, \underline{\mathrm{C}}_{2}\right.$ on $\left.\mathrm{PCL}\right)$, $1.40-1.38$ (m, $\mathrm{CH}_{2}$ on PCL).

FT-IR (ATR): $v\left[\mathrm{~cm}^{-1}\right]$ 3265, 2945, 2865, 1730, 1460, 1410, 1390, 1365, 1295, 1245, 1165, 1105, $1045,1005,960,730$.

\subsection{Synthesis of alkyne end-functionalized poly(L-lactide) (PLA-alkyne)}

The PLA-alkyne was obtained according to the published method; a ROP of LA using $\mathrm{Sn}(\mathrm{Oct})_{2}$ as a catalyst and propargyl alcohol as an initiator [54]. Typically, propargyl alcohol (PA, 210,89 $\mu \mathrm{L}, 3,57 \mathrm{mmol}$ ) and LA ( $5 \mathrm{~g}, 34,69 \mathrm{mmol})$ were added in a flask with a magnetic stirring bar, and a solution of $\mathrm{Sn}(\mathrm{Oct})_{2}$ $(9,64 \mu \mathrm{L}, 0,03 \mathrm{mmol})$ in $5 \mathrm{~mL}$ of toluene was introduced using a syringe. The reactive mixture was deaerated with nitrogen and then immersed in a thermostated oil bath at $120^{\circ} \mathrm{C}$ for $5 \mathrm{~h}$.

After removing the solvent under reduced pressure, the residue was dissolved in dichloromethane and precipitated in cold methanol. The product was subsequently dried under vacuum oven for overnight at room temperature. (Yield $=3,85 \mathrm{~g}, 77 \% ; M_{\mathrm{n} \text {,theo }}=$ $1100 \mathrm{Da} ; M_{\mathrm{n}, \mathrm{NMR}}=1450 \mathrm{Da} ; M_{\mathrm{n}, \mathrm{GPC}}=3200 \mathrm{Da}$; polydispersity index $(\mathrm{PDI})=1.41$.) 
${ }^{1} \mathrm{H}-\mathrm{NMR} \quad\left(600 \mathrm{MHz}, \quad \mathrm{CDCl}_{3}\right): \quad \delta \quad 5.16 \quad(\mathrm{~m}$, (CO) $-\mathrm{C} \underline{H}-\left(\mathrm{CH}_{3}\right)-\mathrm{O}$ on PLA), $4.71 \quad(\mathrm{~s}, 2 \mathrm{H}$, $\left.\mathrm{C} \underline{H}_{2}-\mathrm{C} \equiv \mathrm{CH}\right), 4.34\left(\mathrm{~m},(\mathrm{CO})-\mathrm{C} \underline{H}-\left(\mathrm{CH}_{3}\right) \mathrm{OH}\right.$ endgroup of PLA), $2.50\left(\mathrm{~s}, 1 \mathrm{H}, \mathrm{CH}_{2}-\mathrm{C} \equiv \mathrm{C} \underline{H}\right), 1.48-1.69$ (m, $(\mathrm{CO})-\mathrm{CH}-\left(\mathrm{CH}_{3}\right) \mathrm{O}$ on PLA).

FT-IR (ATR): $v\left[\mathrm{~cm}^{-1}\right]$ 3290, 2980, 2945, 1740, 1460, 1380, 1260, 1180, 1090, 1050, 860, 750, 660.

\subsection{General procedure of CuAAC click reactions}

Firstly, a flask equipped with a stirring bar was preheated via a heat gun. After being closed by a rubber, it was again heated under vacuum and cooled. The PCL-alkyne or PLA-alkyne, PEtOx- $\mathrm{N}_{3}$, copper sulfate $\left(\mathrm{CuSO}_{4}\right)$ and ascorbic acid were dissolved in $\mathrm{N}, \mathrm{N}$-dimethylformamide (DMF) and were added into the flask by a syringe. And then, the mixture was deaerated with nitrogen and stirred at the room temperature in the dark for 24 hours. After the completion of the reaction duration, the reaction mixture was purified by passing through a silica column and the solvent was removed under reduced pressure. Finally, the residue was dissolved in dichloromethane and precipitated in cold diethyl ether and dried under vacuum for overnight.

\subsection{Cytotoxic activities of amphiphilic block copolymers}

22RV1, LnCAP and PNT1A cells were plated into 96 microculture well plates at a density of 2500 cells/well. Polymers were added at various concentrations; 10,20 and $30 \mu \mathrm{L} / \mathrm{mL}$ and incubated for 24, 48 and $72 \mathrm{~h}$. Cytotoxic effect was then assessed by WST1 assay, which was performed according to the manufacturer's instructions. Absorbance value obtained for each sample was used to calculate the percentage of cell viability normalized to non-treated control cells, which was set to $100 \%$.

\subsection{Characterization}

Attenuated total reflectance Fourier transform infrared (ATR-FTIR) spectroscopy measurements were recorded using a Perkin-Elmer Spectrum BX FT-IR spectrometer over the range of $4000-500 \mathrm{~cm}^{-1}$ with a maximum OPD resolution of $1 \mathrm{~cm}^{-1}$. The spectrum BX can operate in ratio, single-beam or interferogram mode. An electronics system based on the Motorola 68340 Integrated Processor. All proton nuclear magnetic resonance $\left({ }^{1} \mathrm{H}-\mathrm{NMR}\right)$ measurements were carried out on a Varian 600 Spectrometer operating at $599.90 \mathrm{MHz}$. The used probe was a Varian's One NMR. The following parameters were employed for acquisition of spectra: spectral width, 16 ppm; acquisition time, $3.4 \mathrm{~s}$; relaxation delay, $1 \mathrm{~s} ; 90^{\circ}$ pulse width, $7.2 \mu \mathrm{s}$; time domain, $64 \mathrm{~K}$ data points; 32 scans; temperature, $298.15 \mathrm{~K}$. The gel permeation chromatography (GPC) measurements were carried out in two different systems: an Agilent instrument (Model 1100) was used for PCL-alkyne, PLA-alkyne and resulting amphiphilic block copolymers, whereas a Viscotek TDA302 GPC instrument was only used for PEtOx- $\mathrm{N}_{3}$. The Agilent systen included a pump, refractive index (RI), and ultraviolet (UV) detectors and four Waters Styragel columns (guard, HR 5E, HR 4E, HR 3, and HR 2), (4.6 mm internal diameter, $300 \mathrm{~mm}$ length, packed with $5 \mu \mathrm{m}$ particles). The effective molecular weight ranges are 2000-4000 000, 50-100000, 500-30000 and 500-20000 respectively. Tetrahydrofuran (THF) was used as eluent at a flow rate of $0.3 \mathrm{~mL} / \mathrm{min}$ at $30^{\circ} \mathrm{C}$ and as an internal standard respectively. The apparent molecular weights ( $M_{\mathrm{n}, \mathrm{GPC}}$ and $\left.M_{\mathrm{w}, \mathrm{GPC}}\right)$ and polydispersity indexes (PDI) were determined with a calibration based on linear polystyrene (PS) standards using PL Caliber Software from Polymer Laboratories. The Viscotek system equipped with a Viscotek GPCmax pump, refractive index and right angle light scattering detectors and a Tosoh TSKGel G3000PWxl $(300 \mathrm{~mm} \times 7.8 \mathrm{~mm})$ column at $25^{\circ} \mathrm{C}$ for poly(2-ethyl-2-oxazoline) as hydrophilic segment. Phosphate buffer saline (PBS, $\mathrm{pH}=7.0$ ) with $0.05 \% \mathrm{NaN}_{3}$ was used as mobile phase and flow rate was $0.8 \mathrm{~mL} / \mathrm{min}$. The detectors were calibrated with poly(ethylene oxide) (10 kDa standard solutions). All samples were filtered with $0.2 \mu \mathrm{m}$ regenerated cellulose syringe filters. Differential scanning calorimetry (DSC) was recorded on a Perkin Elmer Diamond DSC with a heating rate of $10^{\circ} \mathrm{C} \cdot \mathrm{min}^{-1}$ under nitrogen flow $\left(20 \mathrm{~mL} \cdot \mathrm{min}^{-1}\right)$. The method of heat-cool-heat was used in the DSC measurements.

\section{Results and discussion \\ 3.1. Synthesis and characterization of clickable precursors}

The clickable azide- and alkyne-functionalized precursors were prepared according to literature procedure Figure 1. The living CROP of 2-ethyl-2-oxazoline was initiated by methyl $p$-toluenesulfonate (monomer to initiator concentration [M]:[I] was 67:1) and conducted in acetonitrile at $130^{\circ} \mathrm{C}$ and terminated 


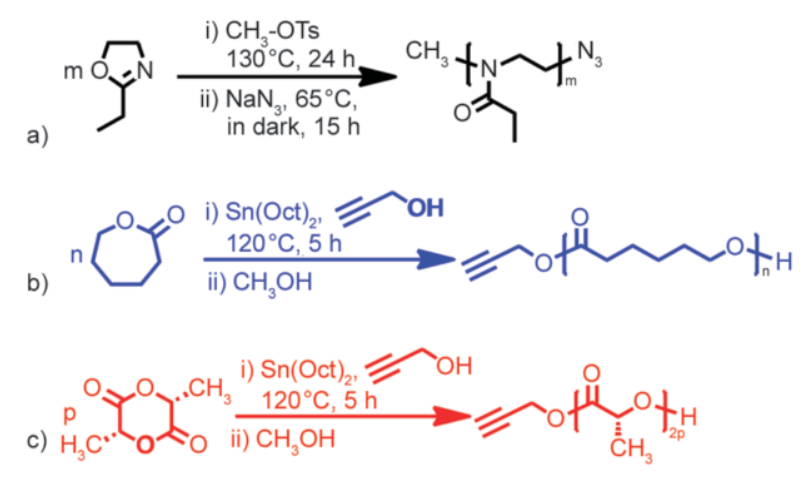

Figure 1. Synthesis of clickable precursors (PEtOx-N 3 , PCLalkyne and PLA-alkyne) via living CROP and coordination-insertion ROP; a) PEtOx-N 3 , b) PCLalkyne, c) PLA-alkyne

with excess sodium azide to obtain an azide-terminated poly(2-ethyl-2-oxazoline) $\left(\mathrm{PEtOx}_{3}\right)$ [51, 55, 56]. After the successful synthesis, its macromolecular structure was confirmed by FT-IR and ${ }^{1} \mathrm{H}-\mathrm{NMR}$ spectroscopies. In the ${ }^{1} \mathrm{H}-\mathrm{NMR}$ spectrum, the peaks around $0.9-1.1,2.2-2.4$ and 3.3-3.5 ppm were assigned to methyl $\left(\mathrm{C}_{3}-\mathrm{CH}_{2}-\mathrm{C}=\mathrm{O}-\right)$, methylene $\left(\mathrm{CH}_{3}-\underline{\mathrm{C}}_{2}-\mathrm{C}=\mathrm{O}-\right)$ and $\left(-\mathrm{N}-\mathrm{C}_{2}-\mathrm{C}_{2}-\mathrm{N}-\right)$ protons of the repeating units. Whereas, the peak at $2.98 \mathrm{ppm}$ was from methyl protons $\left(\mathrm{C}_{3}-\mathrm{N}-\mathrm{CH}_{2}-\mathrm{CH}_{2}-\mathrm{N}-\right)$ of the initiator. Moreover, absence of the aromatic signals of the tosyl group demonstrated the quantitative degree of azide functionalization. In addition, the antisymmetric stretching vibration band of PEtOx- $\mathrm{N}_{3}$ was clearly detected at $2103 \mathrm{~cm}^{-1}$ in the FT-IR spectrum. The number-average molecular weight $\left(M_{\mathrm{n}}\right)$ and polydispersity index (PDI) were measured by gel permeation chromatography and found as $9200 \mathrm{Da}$ and 1.07 , respectively.

On the other hand, clickable PCL-alkyne and PLAalkyne precursors were prepared by coordination-insertion ROP of $\varepsilon$-caprolactone and L-lactide, using tin (II) 2-ethylhexanoate as catalyst and propargyl alcohol as initiator (with $[\mathrm{M}] /[\mathrm{I}]$ ratio $=17.96$ for PCL and 9.72 for PLA) in toluene at $120^{\circ} \mathrm{C}$. The structure of the obtained polymers were also confirmed by FT-IR, ${ }^{1} \mathrm{H}-\mathrm{NMR}$ and GPC analyses. According to the ${ }^{1} \mathrm{H}-\mathrm{NMR}$ analysis of PCL-alkyne, the methylene protons $\left(\mathrm{O}-\mathrm{CH}_{2}-\mathrm{CH}_{2}-\mathrm{CH}_{2}-\mathrm{CH}_{2}-\underline{\mathrm{CH}}_{2}-\mathrm{C}=\mathrm{O}\right)$ of the repeating unit were observed around 1.3-1.4, 1.5-1.7 and 3.9-4.0 ppm. The singlet peaks at 4.6 and $2.3 \mathrm{ppm}$ were attributed to the methylene $\left(\mathrm{CH}_{2}-\mathrm{C} \equiv \mathrm{CH}\right)$ and methine $\left(\mathrm{CH}_{2}-\mathrm{C} \equiv \mathrm{C} \underline{H}\right)$ protons of propargyl alcohol, whereas the triplet peaks at $3.7 \mathrm{ppm}$ were assigned to methylene $\left(\mathrm{CH}_{2} \mathrm{OH}\right)$ protons of PCL end-groups. The characteristic ester and alkyne bands of PCL- alkyne were determined at $1105(\mathrm{C}-\mathrm{O}-\mathrm{C}=\mathrm{O}), 1730$ $(\mathrm{C}=\mathrm{O}), 2100(\mathrm{C} \equiv \mathrm{C})$ and $3265(\mathrm{C} \equiv \mathrm{C}-\mathrm{H}) \mathrm{cm}^{-1}$ in the FT-IR spectrum. According to GPC analysis, the $M_{\mathrm{n}}$ and PDI values of PCL-alkyne were found as $5100 \mathrm{Da}$ and 1.35. Additionally, the PLA-alkyne was prepared and characterized by using similar procedure. In the ${ }^{1} \mathrm{H}-\mathrm{NMR}$ spectrum, the characteristic methine $\left(\mathrm{CH}_{2}-\mathrm{C} \equiv \mathrm{C} \underline{H}\right)$ and methylene $\left(\mathrm{C}_{2}-\mathrm{C} \equiv \mathrm{CH}\right)$ protons of alkyne group were observed at 2.5-2.6 and 4.7$4.8 \mathrm{ppm}$, respectively. On the other hand, the methyl $\left((\mathrm{C}=\mathrm{O})-\mathrm{CH}-\mathrm{C}_{3}\right)$ and methine $\left((\mathrm{C}=\mathrm{O})-\mathrm{C} \underline{H}-\mathrm{CH}_{3}\right)$ protons of the repeating units of PLA were detected around $1.5-1.7$ and $5.2-5.6 \mathrm{ppm}$. Its structure was further confirmed by FT-IR spectroscopy, in which the alkyne and ester groups were detected at 1095 $(\mathrm{C}-\mathrm{O}-\mathrm{C}=\mathrm{O}), 1750(\mathrm{C}=\mathrm{O}), 2090(\mathrm{C} \equiv \mathrm{C})$ and 3280 $(\mathrm{C} \equiv \mathrm{C}-\mathrm{H}) \mathrm{cm}^{-1}$. The $M_{\mathrm{n}}$ and PDI values of PLAalkyne were found as $3200 \mathrm{Da}$ and 1.41 by GPC analysis.

\subsection{Synthesis and characterization of amphiphilic block copolymers}

Finally, the targeted amphiphilic block copolymers, PEtOx- $b$-PCL and PEtOx- $b$-PLA were formed by CuAAC click reactions of PEtOx- $N_{3}$ with PCLalkyne or PLA-alkyne ([PEtOx- $\left.\mathrm{N}_{3}\right]$ :[PCL-alkyne] or $[$ PLA-alkyne $]=1: 1)$. All reactions were catalyzed with copper sulfate as a catalyst and ascorbic acid as a reductant and conducted at room temperature for $24 \mathrm{~h}$ Figure 2. The yields and the molecular weight characteristics of precursors and resulting copolymers were summarized in Table 1.

The successful formation of PEtOx- $b$-PCL and PEtOx- $b$-PLA block copolymers were also monitored

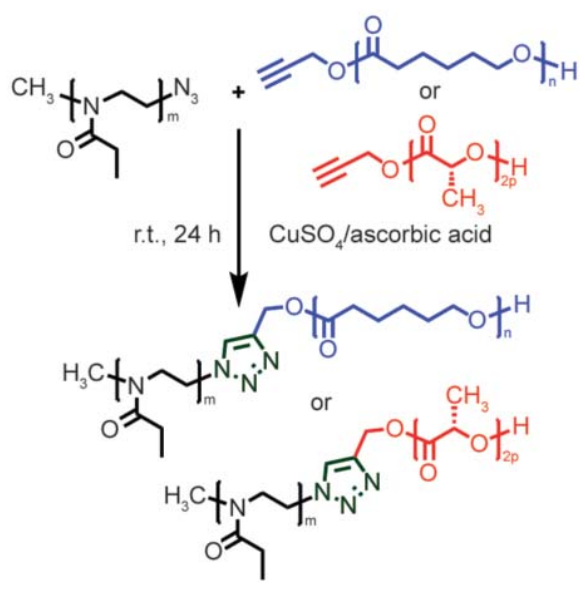

Figure 2. Synthesis of amphiphilic block copolymers (PEtOx$b$-PCL and PEtOx- $b$-PLA) via CuAAC click reactions 
Table 1. The data of precursor polymers (PEtOx-N 3 , PCL-alkyne, PLA-alkyne) and block copolymers (PEtOx- $b$-PCL and PEtOx- $b$-PLA)

\begin{tabular}{|l|c|c|c|c|c|c|c|c|}
\hline \multicolumn{1}{|c|}{ Entry } & $\begin{array}{c}\mathbf{Y i e l d}^{\mathbf{a}} \\
{[\mathbf{\%}]}\end{array}$ & $\begin{array}{c}\boldsymbol{M}_{\mathbf{n}, \text { theo }}{ }^{\mathbf{b}} \\
{[\mathbf{D a}]}\end{array}$ & $\begin{array}{c}\boldsymbol{M}_{\mathbf{n}, \mathbf{N M R}}{ }^{\mathbf{c}} \\
{[\mathbf{D a}]}\end{array}$ & $\begin{array}{c}\boldsymbol{M}_{\mathbf{n}, \mathbf{G P C}}{ }^{\mathbf{d}} \\
{[\mathbf{D a}]}\end{array}$ & $\mathbf{P D I}^{\mathbf{d}}$ & $\begin{array}{c}\boldsymbol{T}_{\mathbf{g}}{ }^{\mathbf{e}} \\
{\left[{ }^{\circ} \mathbf{C}\right]}\end{array}$ & $\begin{array}{c}\boldsymbol{T}_{\mathbf{m}}{ }^{\mathbf{e}} \\
{\left[{ }^{\circ} \mathbf{C}\right]}\end{array}$ & $\boldsymbol{x}_{\mathbf{P E t O x}}{ }^{\mathbf{f}}$ \\
\hline PEtOx-N ${ }_{3}$ & 88.6 & 5850 & 5400 & $9200^{\mathrm{i}}$ & $1.07^{\mathrm{i}}$ & 57 & n.d. & - \\
\hline PCL-alkyne & 81.6 & 1700 & 2500 & 5100 & 1.35 & n.d. & 51 & - \\
\hline PLA-alkyne & 77.0 & 1070 & 1450 & 3200 & 1.41 & 37 & 112 & - \\
\hline PEtOx- $b$-PCL & 94.6 & $7550^{\mathrm{g}}$ & $7100^{\mathrm{h}}$ & 13100 & 1.22 & n.d. & 49 & 68.1 \\
\hline PEtOx- $b$-PLA & 93.2 & $6950^{\mathrm{g}}$ & $6600^{\mathrm{h}}$ & 11300 & 1.28 & 58 & n.d. & 76.7 \\
\hline
\end{tabular}

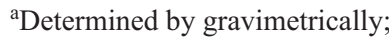

${ }^{\mathrm{b}} M_{\mathrm{n}, \text { theo }}=$ mmonomer $\cdot[\mathrm{M}]_{0} /[\mathrm{I}]_{0} \cdot$ conversion;

${ }^{\mathrm{c} C a l c u l a t e d}$ according the ${ }^{1} \mathrm{H}-\mathrm{NMR}$ analysis;

${ }^{\mathrm{d}}$ Determined by GPC with linear polystyrene standards;

${ }^{\mathrm{e}}$ Determined by DSC with a heating rate of $10{ }^{\circ} \mathrm{C} / \mathrm{min}$ under nitrogen flow $(10 \mathrm{~mL} / \mathrm{min})$;

${ }^{\mathrm{f}}$ Copolymer compositions (x) were calculated according the ${ }^{1} \mathrm{H}-\mathrm{NMR}$ analysis by comparing the integration of the methyl protons of PEtOx (d) with methylene protons (n) of PCL or methyl protons $(k+n)$ of PLA;

${ }^{\mathrm{g}} \mathrm{Sum}$ of $M_{\mathrm{n} \text {,theo }}$ of precursor polymers;

${ }^{\mathrm{h}}$ Calculated according to ${ }^{1} \mathrm{H}-\mathrm{NMR}$ analysis by comparing the integration of triazole proton (g) with methylene protons (n) of PCL or methyl protons $(\mathrm{k}+\mathrm{n})$ of PLA;

iDetermined by GPC with linear poly(ethylene oxide) standard;

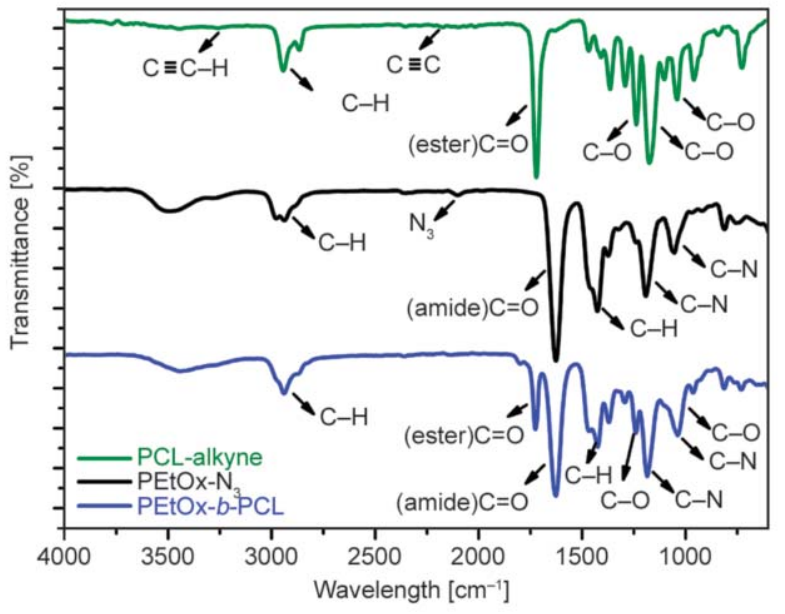

Figure 3. FT-IR spectra of PEtOx- $\mathrm{N}_{3}$, PCL-alkyne and PEtOx- $b$-PCL samples

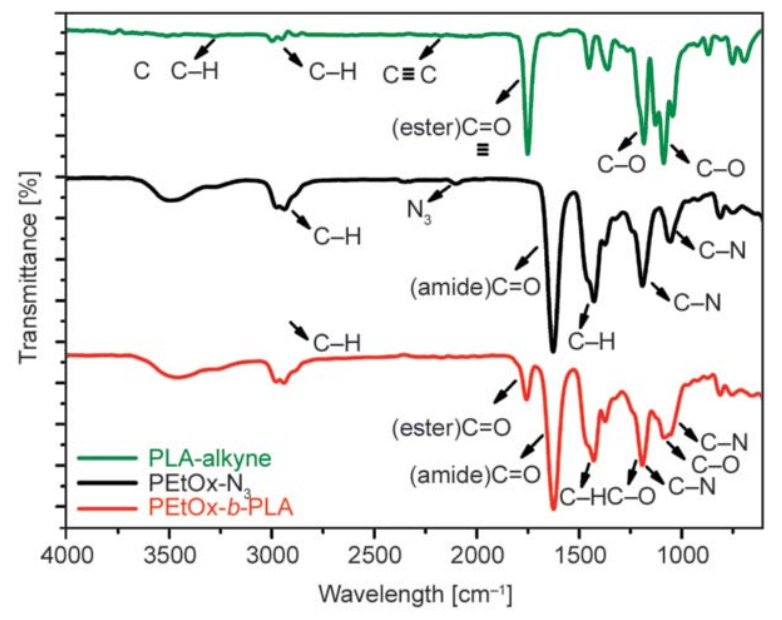

Figure 4. FT-IR spectra of PEtOx- $\mathrm{N}_{3}$, PLA-alkyne and PEtOx- $b$-PLA samples by FT-IR spectroscopy. The characteristic azide band of $\mathrm{PEtOx}-\mathrm{N}_{3}$ at $2103 \mathrm{~cm}^{-1}$ and alkyne bands $(\mathrm{C} \equiv \mathrm{C}$ and $\mathrm{C} \equiv \mathrm{C}-\mathrm{H})$ of PCL-Alkyne and PLA-Alkyne at 2125 and $3320 \mathrm{~cm}^{-1}$ were clearly disappeared, whereas new peaks corresponding to $\mathrm{C}=\mathrm{O}$ and $\mathrm{C}-\mathrm{O}-\mathrm{C}$ bonds of ether groups were appeared at 1728 and $1240 \mathrm{~cm}^{-1}$ for PCL, and 1758 and $1048 \mathrm{~cm}^{-1}$ for PLA. In addition, the characteristic amide, methine, methylene and methyl bands of PEtOx were still presented in both block copolymer samples Figure 3 and 4 . After the click reaction, in ${ }^{1} \mathrm{H}-\mathrm{NMR}$ spectrum of PEtOx- $b$-PCL, a new peak corresponding to triazole ring $(g)$ was observed at around $8.1 \mathrm{ppm}$ Figure 5. Although, the methine $\left(\mathrm{CH}_{2}-\mathrm{C} \equiv \mathrm{C} \underline{H}\right)$ proton of PCLalkyne protons at $2.3 \mathrm{ppm}$ was overlapped with methylene protons (c) of PEtOx, the methylene $\left(\mathrm{C} \underline{H}_{2}-\mathrm{C} \equiv \mathrm{CH}\right)$ protons (h) at $4.6 \mathrm{ppm}$ were clearly shifted to $5.1 \mathrm{ppm}$. On the other hand, the similar results were obtained for PEtOx- $b$-PLA, in which triazole proton was clearly detected, the characteristic methylene protons were quantitatively shifted to $5.2 \mathrm{ppm}$ Figure 6. In addition, the characteristic protons of both PEtOx with PCL or PLA segments were detected and the copolymer composition was calculated using ${ }^{1} \mathrm{H}-\mathrm{NMR}$ spectroscopy data by comparing the integration of the methyl protons (d) of PEtOx with methylene protons $(n)$ of PCL or the methyl protons $(\mathrm{k}+\mathrm{n})$ of PLA. By using similar method, the molecular weights $\left(M_{\mathrm{n}, \mathrm{NMR}}\right)$ of obtained copolymers could be also calculated by using integral ratio of the triazole proton $(\mathrm{g})$ with the methylene protons $(\mathrm{n})$ of 


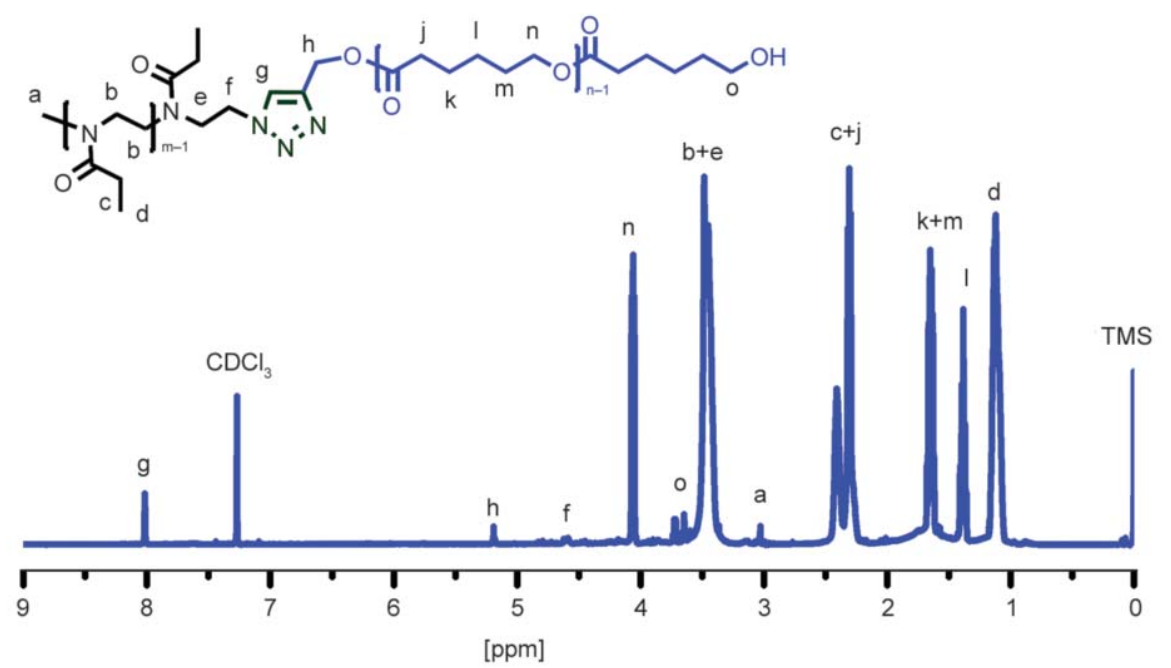

Figure 5. ${ }^{1} \mathrm{H}-\mathrm{NMR}$ spectrum of PEtOx- $b$-PCL sample

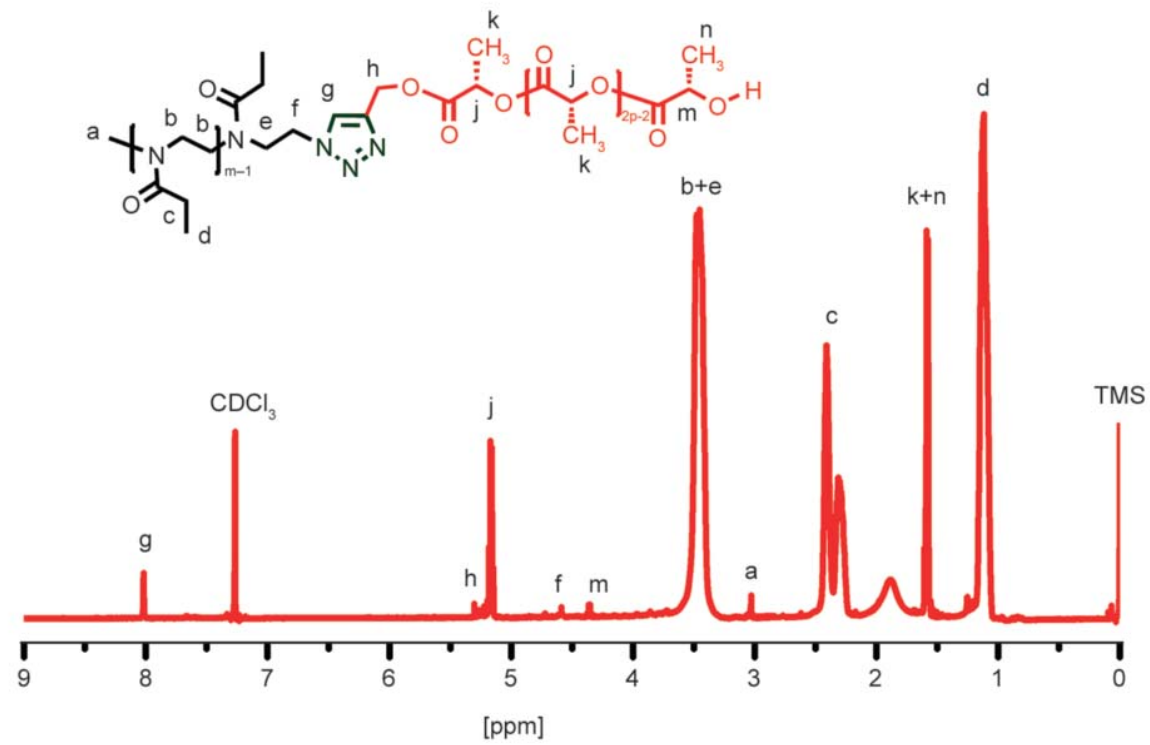

Figure 6. ${ }^{1} \mathrm{H}-\mathrm{NMR}$ spectrum of PEtOx- $b$-PLA sample

PCL or the methyl protons $(k+n)$ of PLA. The obtained molecular weights results were summarized in Table 1 and discussed as follows. According to ${ }^{1} \mathrm{H}-\mathrm{NMR}$ and FT-IR results, successful block copolymer synthesis was achieved by CuAAC click reaction under mild condition.

Successful block copolymer synthesis via CuAAC click reaction was also confirmed by GPC analysis. The GPC chromatograms of initial precursors demonstrated unimodal patterns with narrow molecular weight distributions, which implied that control over molecular weight was achieved by either coordination-insertion ROP or living CROP. After block copolymer formations, the GPC traces of PEtOx- $b$ PCL and PEtOx- $b$-PLA were monomodal and shifted to higher molecular weight regions Figure 7. The increase of $M_{\mathrm{n}}$ of PEtOx- $b$-PCL was higher than
PEtOx- $b$-PLA due to the initial block length. On the other hand, both block copolymers had slightly high molecular weight distributions below than 1.28 compared to PEtOx- $\mathrm{N}_{3}$ homopolymer. Based on GPC and ${ }^{1} \mathrm{H}-\mathrm{NMR}$ results, the ${ }^{1} \mathrm{H}-\mathrm{NMR}$ results were in good agreement with theoretical molecular weights of block copolymers. Since the GPC equipment was calibrated with polystyrene standards, the molecular weights of copolymers were calculated higher than theoretical molecular weights. However, an increase of molecular weights in both PEtOx- $b$-PCL and PEtOx- $b$ PLA block copolymers were clearly observed in GPC chromatograms. The composition of block copolymers were calculated by the ${ }^{1} \mathrm{H}-\mathrm{NMR}$ analysis by comparing the integration of the methyl protons of PEtOx (d) with methylene protons (n) of PCL or methyl protons $(k+n)$ of PLA. The ratio of PEtOx 


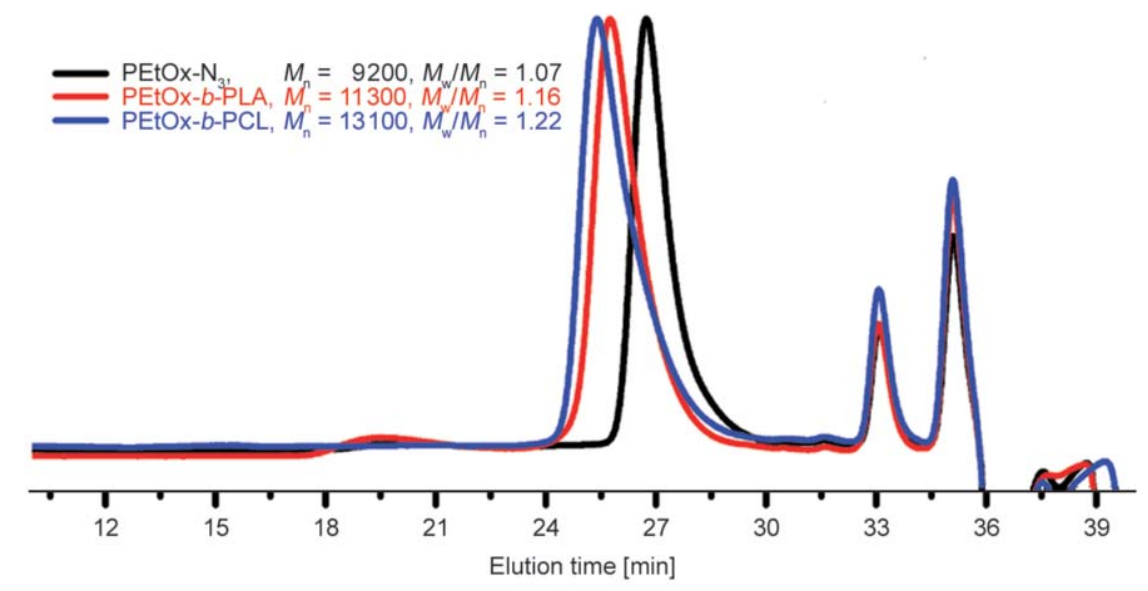

Figure 7. GPC traces of PEtOx-N 3 , PEtOx- $b$-PCL and PEtOx- $b$-PLA block copolymers

block was determined as $68.1 \%$ in PEtOx- $b$-PCL, whereas $76.7 \%$ in PEtOx- $b$-PLA.

\subsection{Thermal behavior of amphiphilic block copolymers}

Thermal transitions of amphiphilic block copolymers and their linear counterparts were investigated to show the influence of chain compositions on these transitions by DSC analysis. The PEtOx was an amorphous polymer that did not have any crystallization or melting transitions, but it exhibited a glass transition temperature $\left(T_{\mathrm{g}}\right)$ at $57^{\circ} \mathrm{C}$. Conversely, the PCL and PLA, were semi-crystalline polymers, exhibited both glass transition and melting points, which were below -60 and $51^{\circ} \mathrm{C}$ for PCL (Due to the cooling limitation of our DSC instrument, $T_{\mathrm{g}}$ of PCL was not determined), and 37 and $112^{\circ} \mathrm{C}$ for PLA [57]. In the case of PEtOx- $b$-PCL, $T_{\mathrm{g}}$ of PEtOx was not detected due to overlapping with the melting peak of PCL, which was shifted from 51 to $49^{\circ} \mathrm{C}$ [58]. Since the PLA block had a short block length, its thermal transitions in the PEtOx- $b$-PLA in such block copolymers strongly depends on the molecular weight of the blocks, were not observed [38]. However, the $T_{\mathrm{g}}$ of PEtOx was slightly improved by addition of semicrystalline PLA block [37].

\subsection{Cytotoxic activities of amphiphilic block copolymers}

The cytotoxicity activities of resulting amphiphilic block copolymers and their precursors were evaluated under in-vitro conditions. For that reason, three different cell types were used to investigate the cytotoxic effect of these polymers on the prostate epithelial and cancer cells. In order to compare the effect of polymers with respect to androgen dependency the hormone-sensitive cell line LnCAP and hormone-resistant cell line 22RV1 was used in the cytotoxicity studies. The PEtOx- $\mathrm{N}_{3}$ polymer significantly induced the proliferation of PNT1A cell line with the percentage of 40 to $50 \%$ Figure $8 \mathrm{a}$. Interestingly, this polymer led to a slight toxic effect on the viability of $22 \mathrm{RV} 1$ cells in the first 24 hours, which was pulled back to control levels for the later time points Figure $8 \mathrm{~b}$. A similar trend in the proliferation rate for LnCAP was detected in that PEtOx$\mathrm{N}_{3}$ polymer treatment resulted in a 40 to $50 \%$ decreased on the cell viability of the LnCAP cell line at 24 and 48 hours, while at 72 hour time point LnCAP cell viability was detected around $90 \%$ in the presence of 10 and $30 \mu \mathrm{L} / \mathrm{ml}$ PEtOx- $\mathrm{N}_{3}$ Figure $8 \mathrm{c}$.

Characterization of PCL-alkyne polymer toxicity for PNT1A cells showed an induction in cell proliferation in a dose-dependent manner at all-time points, while treatment of 22RV1 and LnCAP with this polymer led to a decrease in cell viability at early time points Figure 9a. In the presence of PCL-alkyne, the cell viability of $22 \mathrm{RV} 1$ cells was decrease to $20 \%$ at 24 hours, $30 \%$ at 48 hours and $35 \%$ at 72 hours Figure $9 \mathrm{~b}$. Albeit following a similar trend at the early time points, LnCAP cell viability was returned to control levels at 72 hour-treatment with PCLalkyne at all-concentrations Figure 9c.

Exposure to PLA-alkyne polymer at all concentrations resulted in an approximate $20 \%$ of toxicity in PNT1A cells at 24 and 48 hours, albeit with no detectable toxic effect was evident at 72 hours Figure 10a. Regardless of the treatment concentration PLA-alkyne displayed slight toxicity with a percentage of $20 \%$ to $22 \mathrm{RV} 1$ cells Figure 10b. PLA-alkyne 

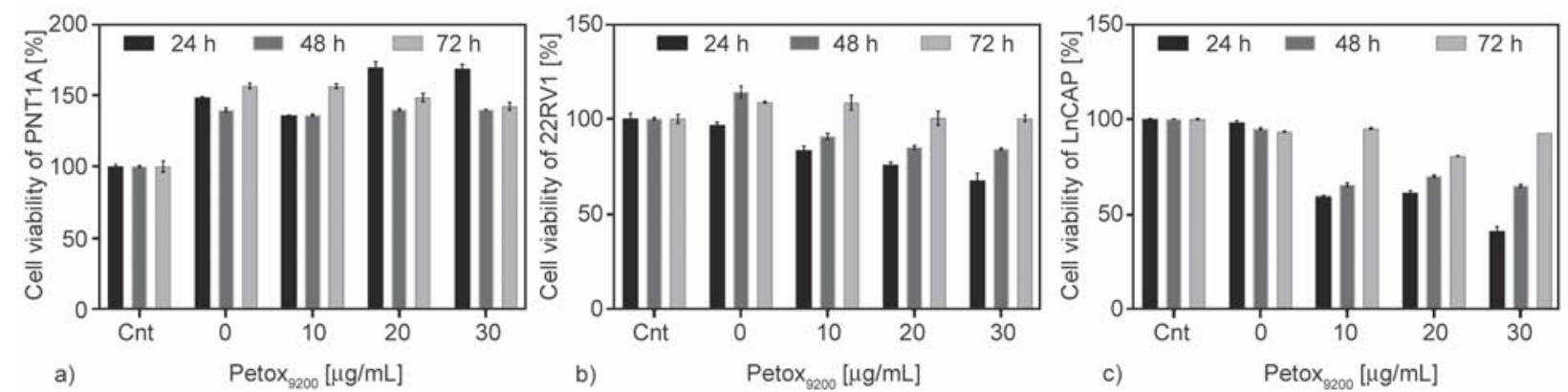

Figure 8. Cytotoxic effect of PEtOx-N 3 on PNT1A, 22RV1 and LnCAP cell lines. Percentage of cell viability of PNT1A (a), 22RV1 (b), and LnCAP (c). Each data point represents to the mean percentage of viable cells at different time points with three different concentrations $(0-30 \mu \mathrm{L} / \mathrm{mL})$ of at least three separate experiments performed for each concentration. The percentage of cell viability was calculated by assigning the absorbance value obtained from non-treated cells as $100 \%$ for each time point (Cnt: control experiment).
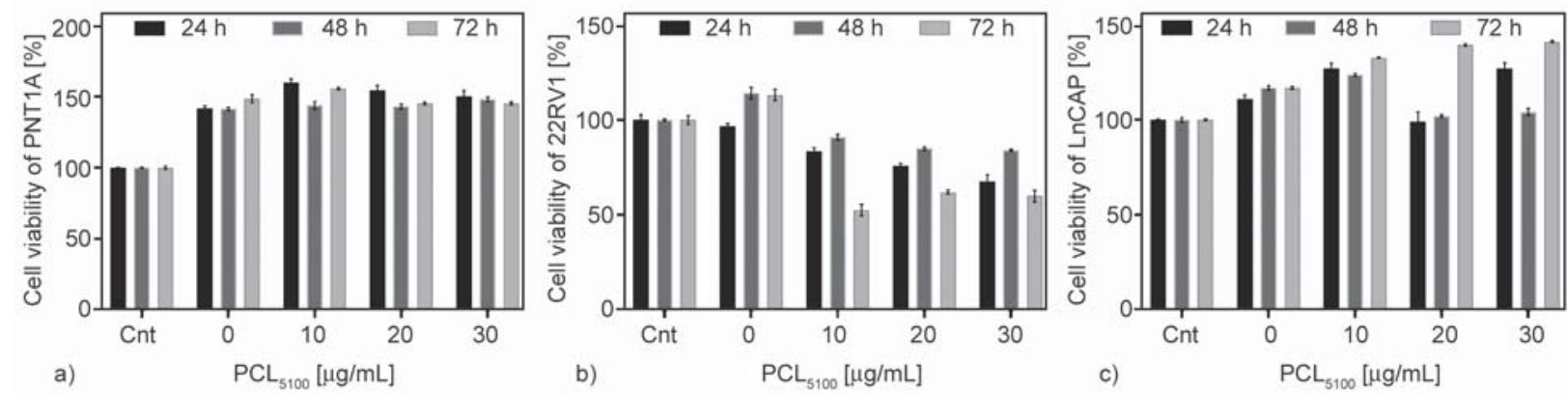

Figure 9. Cytotoxic effect of PCL-alkyne on PNT1A, 22RV1 and LnCAP cell lines. Percentage of cell viability of PNT1A (a), 22RV1 (b), and LnCAP (c). Similar method in Figure 8 was used.
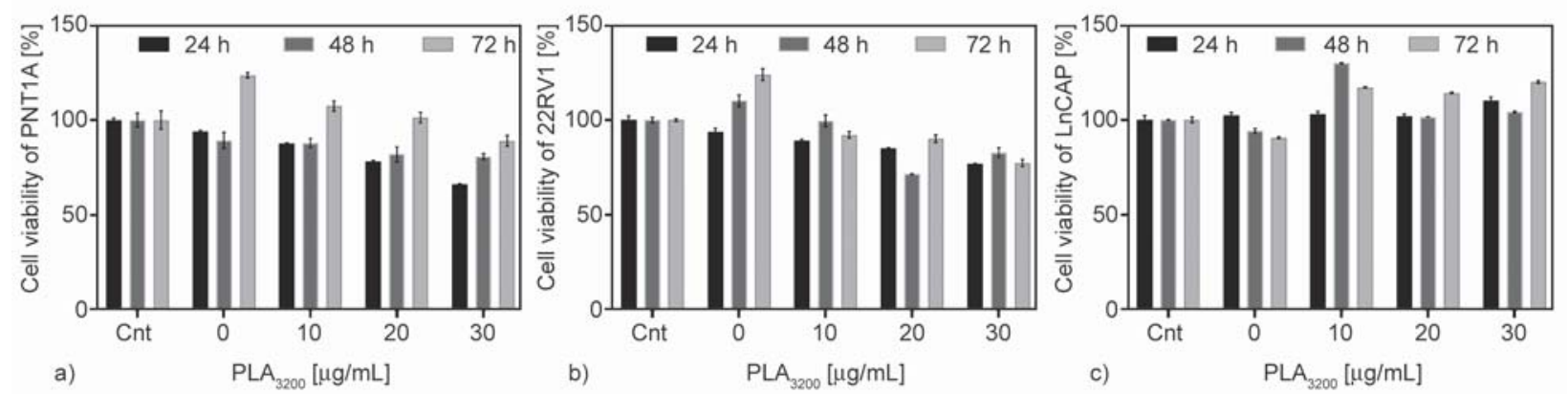

Figure 10. Cytotoxic effect of PLA-alkyne on PNT1A, 22RV1 and LnCAP cell lines. Percentage of cell viability of PNT1A (a), 22RV1 (b), and LnCAP (c). Similar method in Figure 8 was used.

polymer exhibited was not only a non-toxic but also slight proliferative effect the LnCAP cell line in time and dose independent manner Figure 10c.

The treatment of PNT1A cells with PEtOx- $b$-PCL polymer resulted in an $30 \%$ increase of cell proliferation at all concentrations for the three time points tested Figure 11a. Similarly, a significant cell proliferation (40-50\%) was evaluated for 22RV1 cells at 72 hour time point Figure 11b. For LnCAP cell line this polymer displayed a slight toxicity with a $10 \%$ at the 10 and $20 \mu \mathrm{L} / \mathrm{mL}$, while a $30 \%$ decrease in LnCAP cell viability at $30 \mu \mathrm{L} / \mathrm{mL}$ for 48 and 72 hours Figure 11c.
The PEtOx- $b$-PLA led to increase cell proliferation rate in PNT1A cells at all the doses tested Figure 12a. Although this polymer showed no toxicity at the 10 and $20 \mu \mathrm{L} / \mathrm{mL}$ on $22 \mathrm{RV} 1$ cells, a moderate toxicity of this polymer at $30 \mu \mathrm{L} / \mathrm{mL}$ was evident for these androgen independent cells Figure 12b. Likewise, on the androgen dependent cell line LnCAP, the PEtOx$b$-PLA showed moderate toxicity effect by decreasing the cell viability by $15 \%$ at the tested doses Figure $12 \mathrm{c}$.

To summary, the treatment of the healthy prostate epithelial cell line PNT1A with 5 different polymers revealed that no significant cytotoxicity instead the 


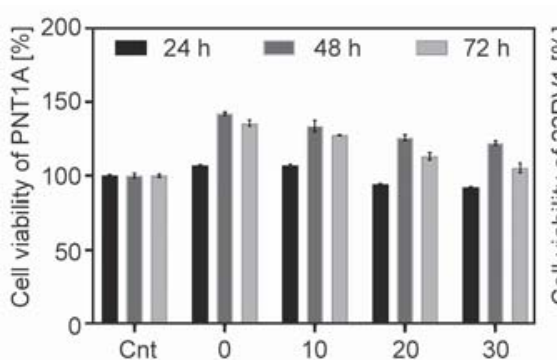

a)

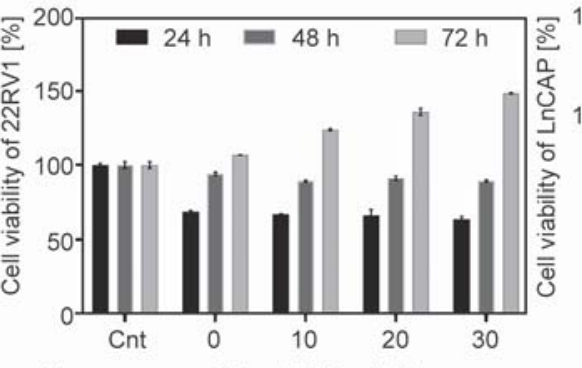

b)

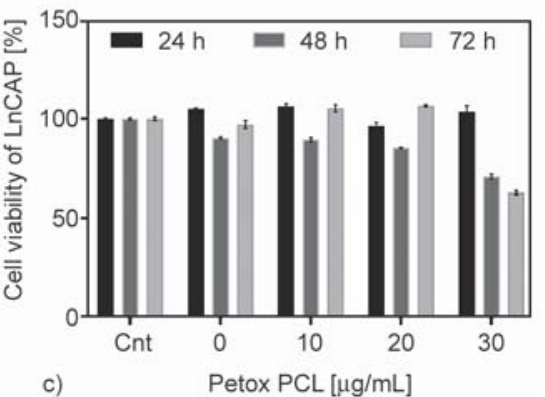

c)

Petox PCL $[\mu \mathrm{g} / \mathrm{mL}]$

Figure 11. Cytotoxic effect of PEtOx- $b$-PCL on PNT1A, 22RV1 and LnCAP cell lines. Percentage of cell viability of PNT1A (a), 22RV1 (b), and LnCAP (c). Similar method in Figure 8 was used.
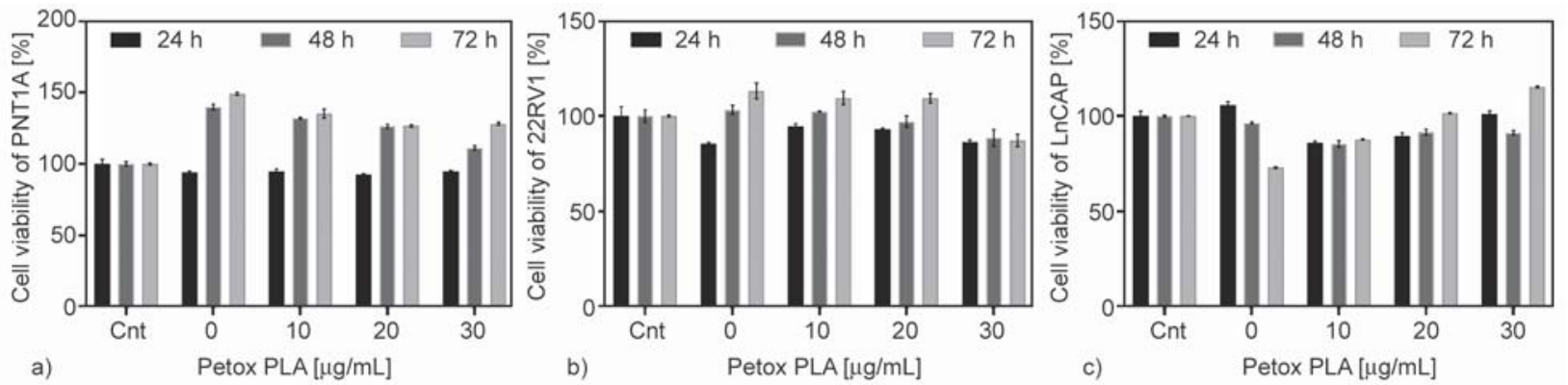

Figure 12. Cytotoxic effect of PEtOx- $b$-PLA on PNT1A, 22RV1 and LnCAP cell lines. Percentage of cell viability of PNT1A (a), 22RV1 (b), and LnCAP (c). Similar method in Figure 8 was used.

cell proliferation rate of PNT1A cells significantly increased once exposed to these polymers. On the other hand, these polymers showed some significant toxic effects on the prostate cancer cell lines. The PEtOx- $b$-PLA revealed a moderate toxicity in both prostate cancer lines while PLA-alkyne sample possessed significant cytotoxic effect only on 22RV1 cells suggesting that the androgen dependency might have a role in the effect of cytotoxicity of PLAalkyne sample. Similarly, in cytotoxic studies carried out on human dermal fibroblast (HDF) cells with PEtOx- $b$-PLA, a slight cytotoxic effect was found at lower concentrations [59]. Given that uptake routes of homo- and co-polymers differs between cancer and healthy cells, and cationic polymers were known to distrupt the integrity of the plasma membrane, cancer cells with their high rate of cellular uptake and fragile plasma-membrane integrity were expected to exhibit increased cytotoxicity after polymer treatment than their healty counterpart [60]. In contrast, a study carried by Hsiue and coworkers found a marked cytotoxicity for PEtOx- $b$-PLA at higher concentrations on non-small cell lung carcinoma [61]. Although PEtOx- $\mathrm{N}_{3}$ and PCL-alkyne led to decrease cell viability at early time points for $22 \mathrm{RV} 1$ and LnCAP cells at later time points this effect was compensated and the viable cell number for 22RV1 and LnCAP cells was comparable to the non-treated con- trol pointing at a possible cytostatic effect of these polymers. According to the study conducted by Luxenhofer and coworkers, the cytotoxicity of PEtOxs on healthy and cancer cells may have vary due to their chemical and physical properties [62].

\section{Conclusions}

In conclusion, well-defined amphiphilic block copolymers containing poly(2-ethyl-2-oxazoline) as hydrophilic block and poly(E-caprolactone) or poly(L-lactide) as hydrophobic block were successfully synthesized by combination of CuAAC click chemistry with either coordination-insertion or living cationic ring-opening polymerization. The results indicated that the CuAAC click reactions can be used to combine mechanistically incompatible blocks (PEtOx, PCL and PLA) in a single molecule under mild conditions. The cytotoxicity activities of resulting amphiphilic block copolymers and their precursors were investigated in the prostate epithelial and cancer cells under in-vitro conditions. The results indicated that PEtOx- $b$-PCL and PEtOx- $b$ PLA displayed no toxic effect on the healthy prostate epithelial cells but on prostate cancer cell lines, therefore, it will be an excellent candidates in biomedical applications such as pharmaceutics, drug delivery systems, stabilizing agents, cosmetics and processing aids. 


\section{Acknowledgements}

The authors would like to thank Turkish Scientific and Technological Council (TUBITAK-213M725) for financial supports.

\section{References}

[1] Adams M. L., Lavasanifar A., Kwon G. S.: Amphiphilic block copolymers for drug delivery. Journal of Pharmaceutical Sciences, 92, 1343-1355 (2003).

https://doi.org/10.1002/jps.10397

[2] Klaikherd A., Nagamani C., Thayumanavan S.: Multistimuli sensitive amphiphilic block copolymer assemblies. Journal of the American Chemical Society, 131, 4830-4838 (2009). https://doi.org/10.1021/ja809475a

[3] Lee S. B., Russell A. J., Matyjaszewski K.: ATRP synthesis of amphiphilic random, gradient, and block copolymers of 2-(dimethylamino)ethyl methacrylate and $n$ butyl methacrylate in aqueous media. Biomacromolecules, 4, 1386-1393 (2003).

https://doi.org/10.1021/bm034126a

[4] Yagci Y., Tasdelen M. A.: Mechanistic transformations involving living and controlled/living polymerization methods. Progress in Polymer Science, 31, 1133-1170 (2006).

https://doi.org/10.1016/j.progpolymsci.2006.07.003

[5] Yenice Z., Tasdelen M. A., Oral A., Guler C., Yagci Y.: Poly(styrene- $b$-tetrahydrofuran)/clay nanocomposites by mechanistic transformation. Journal of Polymer Science Part A: Polymer Chemistry, 47, 2190-2197 (2009). https://doi.org/10.1002/pola.23332

[6] Tasdelen M. A., Beyazit S., Gunes D., Bicak N., Tatar P., Demirel A. L., Yagci Y.: Poly(p-phenylene methylene)based block copolymers by mechanistic transformation. Journal of Polymer Science Part A: Polymer Chemistry, 49, 4021-4026 (2011).

https://doi.org/10.1002/pola.24844

[7] Mansfeld U., Pietsch C., Hoogenboom R., Becer C. R., Schubert U. S.: Clickable initiators, monomers and polymers in controlled radical polymerizations - A prospective combination in polymer science. Polymer Chemistry, 1, 1560-1598 (2010).

https://doi.org/10.1039/c0py00168f

[8] Binder W. H., Sachsenhofer R.: 'Click' chemistry in polymer and materials science. Macromolecular Rapid Communications, 28, 15-54 (2007). https://doi.org/10.1002/marc.200600625

[9] Lutz J-F.: 1,3-dipolar cycloadditions of azides and alkynes: A universal ligation tool in polymer and materials science. Angewandte Chemie: International Edition, 46, 1018-1025 (2007).

https://doi.org/10.1002/anie.200604050

[10] Sumerlin B. S., Vogt A. P.: Macromolecular engineering through click chemistry and other efficient transformations. Macromolecules, 43, 1-13 (2010).

https://oi.org/10.1021/ma901447e
[11] Kolb H. C., Finn M. G., Sharpless K. B.: Click chemistry: Diverse chemical function from a few good reactions. Angewandte Chemie: International Edition, 40, 2004-2021 (2001).

https://doi.org/10.1002/1521-

3773(20010601)40:11<2004::aid-anie2004>3.0.co;2-5

[12] Moses J. E., Moorhouse A. D.: The growing applications of click chemistry. Chemical Society Reviews, 36, 1249-1262 (2007).

https://doi.org/10.1039/b613014n

[13] Akeroyd N., Klumperman B.: The combination of living radical polymerization and click chemistry for the synthesis of advanced macromolecular architectures. European Polymer Journal, 47, 1207-1231 (2011). https://doi.org/10.1016/j.eurpolymj.2011.02.003

[14] Opsteen J. A., van Hest J. C. M.: Modular synthesis of block copolymers via cycloaddition of terminal azide and alkyne functionalized polymers. Chemical Communications, 2005, 57-59 (2005).

https://doi.org/10.1039/b412930j

[15] Opsteen J. A., van Hest J. C. M.: Modular synthesis of ABC type block copolymers by 'click' chemistry. Journal of Polymer Science Part A: Polymer Chemistry, 45, 2913-2924 (2007).

https://doi.org/10.1002/pola.22047

[16] Fournier D., Hoogenboom R., Schubert U. S.: Clicking polymers: A straightforward approach to novel macromolecular architectures. Chemical Society Reviews, 36, 1369-1380 (2007).

https://doi.org/10.1039/b700809k

[17] Golas P. L., Matyjaszewski K.: Marrying click chemistry with polymerization: Expanding the scope of polymeric materials. Chemical Society Reviews, 39, 1338-1354 (2010).

https://doi.org/10.1039/b901978m

[18] Durmaz H., Dag A., Altintas O., Erdogan T., Hizal G., Tunca U.: One-pot synthesis of ABC type triblock copolymers via in situ click [3+2] and Diels-Alder [4+2] reactions. Macromolecules, 40, 191-198 (2007).

https://doi.org/10.1021/ma0618191

[19] Durmaz H., Hizal G., Tunca U.: Linear tetrablock quaterpolymers via triple click reactions, azide-alkyne, DielsAlder, and nitroxide radical coupling in a one-pot fashion. Journal of Polymer Science Part A: Polymer Chemistry, 49, 1962-1968 (2011).

https://doi.org/10.1002/pola.24622

[20] Candan O. A., Durmaz H., Hizal G., Tunca U.: Quadruple click reactions for the synthesis of cysteine-terminated linear multiblock copolymers. Journal of Polymer Science Part A: Polymer Chemistry, 50, 2863-2870 (2012). https://doi.org/10.1002/pola.26063

[21] Omurtag P. S., Gunay U. S., Dag A., Durmaz H., Hizal G., Tunca U.: Diels-Alder click reaction for the preparation of polycarbonate block copolymers. Journal of Polymer Science Part A: Polymer Chemistry, 51, 22522259 (2013).

https://doi.org/10.1002/pola.26608 
[22] Isaacman M. J., Barron K. A., Theogarajan L. S.: Clickable amphiphilic triblock copolymers. Journal of Polymer Science Part A: Polymer Chemistry, 50, 2319-2329 (2012). https://doi.org/10.1002/pola.25989

[23] Riva R., Schmeits S., Jérôme C., Jérôme R., Lecomte P.: Combination of ring-opening polymerization and 'click chemistry': Toward functionalization and grafting of poly( $\varepsilon$-caprolactone). Macromolecules, 40, 796-803 (2007). https://doi.org/10.1021/ma0624090

[24] Riva R., Schmeits P., Stoffelbach F., Jérôme C., Jérôme R., Lecomte P.: Combination of ring-opening polymerization and 'click' chemistry towards functionalization of aliphatic polyesters. Chemical Communications, 2005, 5334-5336 (2005)

https://doi.org/10.1039/B510282K

[25] Ikada Y., Tsuji H.: Biodegradable polyesters for medical and ecological applications. Macromolecular Rapid Communications, 21, 117-132 (2000).

https://doi.org/10.1002/(sici)15213927(20000201)21:3<117::aid-marc117>3.3.co;2-o

[26] Albertsson A-C., Varma I. K.: Recent developments in ring opening polymerization of lactones for biomedical applications. Biomacromolecules, 4, 1466-1486 (2003). https://doi.org/10.1021/bm034247a

[27] Nair L. S., Laurencin C. T.: Biodegradable polymers as biomaterials. Progress in Polymer Science, 32, 762-798 (2007).

https://doi.org/10.1016/j.progpolymsci.2007.05.017

[28] Schlaad H., Diehl C., Gress A., Meyer M., Demirel A. L., Nur Y., Bertin A.: Poly(2-oxazoline)s as smart bioinspired polymers. Macromolecular Rapid Communications, 31, 511-525 (2010).

https://doi.org/10.1002/marc.200900683

[29] Sedlacek O., Monnery B. D., Filippov S. K., Hoogenboom R., Hruby M.: Poly(2-oxazoline)s - Are they more advantageous for biomedical applications than other polymers? Macromolecular Rapid Communications, 33, 1648-1662 (2012).

https://doi.org/10.1002/marc.201200453

[30] Hoogenboom R.: Poly(2-oxazoline)s: A polymer class with numerous potential applications. Angewandte Chemie International Edition, 48, 7978-7994 (2009). https://doi.org/10.1002/anie.200901607

[31] Schulz A., Jaksch S., Schubel R., Wegener E., Di Z., Han Y., Meister A., Kressler J., Kabanov A. V., Luxenhofer R., Papadakis C. M., Jordan R.: Drug-induced morphology switch in drug delivery systems based on poly (2-oxazoline)s. ACS Nano, 8, 2686-2696 (2014). https://doi.org/10.1021/nn406388t

[32] de la Rosa V. R.: Poly(2-oxazoline)s as materials for biomedical applications. Journal of Materials Science: Materials in Medicine, 25, 1211-1225 (2014). https://doi.org/10.1007/s10856-013-5034-y
[33] He Z., Miao L., Jordan R., S-Manickam D., Luxenhofer R., Kabanov A. V.: A low protein binding cationic poly (2-oxazoline) as non-viral vector. Macromolecular Bioscience, 15, 1004-1020 (2015).

https://doi.org/10.1002/mabi.201500021

[34] van Kuringen H. P. C., Lenoir J., Adriaens E., Bender J., de Geest B. G., Hoogenboom R.: Partial hydrolysis of poly(2-ethyl-2-oxazoline) and potential implications for biomedical applications? Macromolecular Bioscience, 12, 1114-1123 (2012). https://doi.org/10.1002/mabi.201200080

[35] Hoogenboom R., Schlaad H.: Bioinspired poly(2-oxazoline)s. Polymers, 3, 467-488 (2011).

https://doi.org/10.3390/polym3010467

[36] Rossegger E., Schenk V., Wiesbrock F.: Design strategies for functionalized poly(2-oxazoline)s and derived materials. Polymers, 5, 956-1011 (2013). https://doi.org/10.3390/polym5030956

[37] Wang X., Li X., Li Y., Zhou Y., Fan C., Li W., Ma S., Fan Y., Huang Y., Li N., Liu Y.: Synthesis, characterization and biocompatibility of poly(2-ethyl-2-oxazoline)-poly(D,L-lactide)-poly(2-ethyl-2-oxazoline) hydrogels. Acta Biomaterialia, 7, 4149-4159 (2011). https://doi.org/10.1016/j.actbio.2011.07.011

[38] Wang C-H., Hsiue G-H.: New amphiphilic poly(2ethyl-2-oxazoline)/poly(L-lactide) triblock copolymers. Biomacromolecules, 4, 1487-1490 (2003). https://doi.org/10.1021/bm034190s

[39] Zhang N., Pompe T., Amin I., Luxenhofer R., Werner C., Jordan R.: Tailored poly(2-oxazoline) polymer brushes to control protein adsorption and cell adhesion. Macromolecular Bioscience, 12, 926-936 (2012). https://doi.org/10.1002/mabi.201200026

[40] Saegusa T., Kobayashi S., Yamada A.: Kinetics and mechanism of the isomerization polymerization of 2methyl-2-oxazoline by benzyl chloride and bromide initiators. Effect of halogen counteranions. Macromolecular Chemistry and Physics, 177, 2271-2283 (1976). https://doi.org/10.1002/macp.1976.021770805

[41] Glassner M., D’hooge D. R., Park J. Y., van Steenberge P. H., Monnery B. D., Reyniers M-F., Hoogenboom R.: Systematic investigation of alkyl sulfonate initiators for the cationic ring-opening polymerization of 2-oxazolines revealing optimal combinations of monomers and initiators. European Polymer Journal, 65, 298-304 (2015).

https://doi.org/10.1016/j.eurpolymj.2015.01.019

[42] Guillerm B., Monge S., Lapinte V., Robin J-J.: How to modulate the chemical structure of polyoxazolines by appropriate functionalization. Macromolecular Rapid Communications, 33, 1600-1612 (2012). https://doi.org/10.1002/marc.201200266 
[43] Guis C., Cheradame H.: Synthesis of polymers containing pseudohalide groups by cationic polymerization 15 . Study of the functionalizing living cationic polymerization of 2-methyl-2-oxazoline in the presence of trimethylsilylazide. European Polymer Journal, 36, $2581-$ 2590 (2000).

https://doi.org/10.1016/S0014-3057(00)00071-9

[44] Hoogenboom R., Fijten M. W. M., Meier M. A., Schubert U. S.: Living cationic polymerizations utilizing an automated synthesizer: High-throughput synthesis of polyoxazolines. Macromolecular Rapid Communications, 24, 92-97 (2003).

https://doi.org/10.1002/marc.200390003

[45] Park J-S., Akiyama Y., Winnik F. M., Kataoka K.: Versatile synthesis of end-functionalized thermosensitive poly(2-isopropyl-2-oxazolines). Macromolecules, 37, 6786-6792 (2004).

https://doi.org/10.1021/ma049677n

[46] Aoi K., Okada M.: Polymerization of oxazolines. Progress in Polymer Science, 21, 151-208 (1996). https://doi.org/10.1016/0079-6700(95)00020-8

[47] Hoogenboom R., Fijten M. W. M., Schubert U. S.: Parallel kinetic investigation of 2-oxazoline polymerizations with different initiators as basis for designed copolymer synthesis. Journal of Polymer Science Part A: Polymer Chemistry, 42, 1830-1840 (2004).

https://dx.doi.org/10.1002/pola.20024

[48] Lava K., Verbraeken B., Hoogenboom R.: Poly(2-oxazoline)s and click chemistry: A versatile toolbox toward multi-functional polymers. European Polymer Journal, 65, 98-111 (2015).

https://doi.org/10.1016/j.eurpolymj.2015.01.014

[49] Luxenhofer R., Jordan R.: Click chemistry with poly(2oxazoline)s. Macromolecules, 39, 3509-3516 (2006). https://doi.org/10.1021/ma052515m

[50] Bauer M., Lautenschlaeger C., Kempe K., Tauhardt L., Schubert U. S., Fischer D.: Poly(2-ethyl-2-oxazoline) as alternative for the stealth polymer poly(ethylene glycol): Comparison of in-vitro cytotoxicity and hemocompatibility. Macromolecular Bioscience, 12, 986-998 (2012).

https://doi.org/10.1002/mabi.201200017

[51] Volet G., Lav T-X., Babinot J., Amiel C.: Click-chemistry: An alternative way to functionalize poly(2-methyl2-oxazoline). Macromolecular Chemistry and Physics, 212, 118-124 (2011).

https://doi.org/10.1002/macp.201000556

[52] Wiesbrock F., Hoogenboom R., Abeln C. H., Schubert U. S.: Single-mode microwave ovens as new reaction devices: Accelerating the living polymerization of 2ethyl-2-oxazoline. Macromolecular Rapid Communications, 25, 1895-1899 (2004).

https://doi.org/10.1002/marc.200400369
[53] Tasdelen M. A.: Poly(epsilon-caprolactone)/clay nanocomposites via 'click'chemistry. European Polymer Journal, 47, 937-941 (2011).

https://doi.org/10.1016/j.eurpolymj.2011.01.004

[54] Enomoto-Rogers Y., Iwata T.: Synthesis of xylan-graftpoly(L-lactide) copolymers via click chemistry and their thermal properties. Carbohydrate Polymers, 87, 19331940 (2012).

https://doi.org/10.1016/j.carbpol.2011.09.092

[55] Rudolph T., Crotty S., Schubert U. S., Schacher F. H.: Star-shaped poly(2-ethyl-2-oxazoline) featuring a porphyrin core: Synthesis and metal complexation. e-Polymers, 15, 227-235 (2015).

https://doi.org/10.1515/epoly-2015-0041

[56] von der Ehe C., Kempe K., Bauer M., Baumgaertel A., Hager M. D., Fischer D., Schubert U. S.: Star-shaped block copolymers by copper-catalyzed azide-alkyne cycloaddition for potential drug delivery applications. Macromolecular Chemistry and Physics, 213, 21462156 (2012). https://doi.org/10.1002/macp.201200307

[57] Kim C., Lee S. C., Kwon I. C., Chung H., Jeong S. Y.: Complexation of poly(2-ethyl-2-oxazoline)-block-poly ( $\varepsilon$-caprolactone) micelles with multifunctional carboxylic acids. Macromolecules, 35, 193-200 (2002). https://doi.org/10.1021/ma0105111

[58] Lee S. C., Chang Y., Yoon J-S., Kim C., Kwon I. C., Kim Y-H., Jeong S. Y.: Synthesis and micellar characterization of amphiphilic diblock copolymers based on poly (2-ethyl-2-oxazoline) and aliphatic polyesters. Macromolecules, 32, 1847-1852 (1999).

https://doi.org/10.1021/ma981664k

[59] Wang X., Li X., Li Y., Zhou Y., Fan C., Li W., Ma S., Fan Y., Huang Y., Li N., Liu Y.: Synthesis, characterization and biocompatibility of poly(2-ethyl-2-oxazoline)-poly(D,L-lactide)-poly(2-ethyl-2-oxazoline) hydrogels. Acta Biomaterialia, 7, 4149-4159 (2011). https://doi.org/10.1016/j.actbio.2011.07.011

[60] Frohlich E.: The role of surface charge in cellular uptake and cytotoxicity of medical nanoparticles. International Journal of Nanomedicine, 7, 5577-5591 (2012). https://doi.org/10.2147/IJN.S36111

[61] Hsiue G-H., Wang C-H., Lo C-L., Wang C-H., Li J-P., Yang J-L.: Environmental-sensitive micelles based on poly(2-ethyl-2-oxazoline)- $b$-poly(L-lactide) diblock copolymer for application in drug delivery. International Journal of Pharmaceutics, 317, 69-75 (2006). https://doi.org/10.1016/j.ijpharm.2006.03.002

[62] Luxenhofer R., Han Y., Schulz A., Tong J., He Z., Kabanov A. V., Jordan R.: Poly(2-oxazoline)s as polymer therapeutics. Macromolecular Rapid Communications, 33, 1613-1631 (2012). https://doi.org/10.1002/marc.201200354 